\title{
Microbial retention and resistances in stormwater quality improvement devices
}

Renato Liguori ${ }^{1,2}$, Steffen H. Rommel ${ }^{1}$, Johan Bengtsson-Palme ${ }^{3,4}$, Brigitte

\section{Affiliations:}

1 Technical University of Munich, Chair of Urban Water Systems Engineering, Am Coulombwall 3, 85748 Garching, Germany direzionale Isola -C4, 80143, Napoli, Italy

3 Department of Infectious Diseases, Institute of Biomedicine, The Sahlgrenska Academy, University of Gothenburg, Guldhedsgatan 10A, SE-413 46, Gothenburg, Sweden

4 Centre for Antibiotic Resistance Research (CARe) at University of Gothenburg, Gothenburg, Sweden

Corresponding to: C. Wurzbacher (christian@wurzbacher.cc), R. Liguori

\section{Abstract}

Current knowledge about the microbial communities that occur in in urban road runoff is scarce. Road runoff of trafficked roads can be heavily polluted and is treated by stormwater quality improvement devices (SQIDs). However, microbes may influence the treatment process of these devices or could lead to stress resistant opportunistic microbial strains. In 
24 this study, the microbial community in the influent, effluent and the filter materials for the removal of dissolved heavy metals of two different SQIDs were analyzed to determine the microbial load, retention, composition, and mobile resistance genes. Although the microbes were replaced by new taxa in the effluent, there was no major retention of microbial genera. Further, the bacterial abundance of the SQIDs effluent was relatively stable over time. The heavy metal content correlated with int/1 and with microbial genera. The filter media itself was enriched with Int/1 gene cassettes, carrying several heavy metal and multidrug resistance genes (e.g. $c z r A, c z c A$, silP, mexW and mexI), indicating that this is a hot spot for horizontal gene transfer. Overall, the results shed light on road runoff microbial communities, and pointed to distinct bacterial communities within the SQIDs, which subsequently influence the microbial community and the genes released with the treated water.

Keywords: pollution, traffic area runoff, microbial communities, heavy metals, stormwater treatment, manufactured treatment devices, sustainable urban drainage systems 


\section{INTRODUCTION}

Industrialization and technological advancement have put an increasing burden on the environment by releasing large quantities of hazardous contaminants inflicting serious damage on the ecosystem. Traffic area runoff is widely recognized as a major transport vector of pollutants released in the urban environment, as it collects precipitation and snowmelt-related discharges of mostly impervious surfaces (e.g. sidewalks, parking lots, feeder streets, major roads, and highways). The majority of pollution caused by traffic area runoff originates from vehicle brake emissions, tire wear, lubricating oil and grease, pet waste and atmospheric deposition on the road surface (1-3). The chemical quality of traffic area runoff has been analyzed and indicated the presence of different contaminants including heavy metals, polycyclic aromatic hydrocarbons, polychlorinated biphenyls (PCB), and other organics $(4,5)$. Heavy metals in traffic area runoff continue to create serious global health concerns, as they persist in suspended particulate matter and have the ability to travel long distances through water-air-soil systems with subsequent risks to human health (6).

The awareness of stormwater runoff pollution and increasing concern about its impacts on the environment, has led to the development of stormwater control measures (SCMs) for pollution control and contaminant retention from urban road runoff. One SCM to minimize the contaminant emissions to the environment is the usage of sustainable urban drainage systems $(7,8)$. These include decentralized technical systems, referred as stormwater quality improvement devices (SQIDs) or manufactured treatment devices that treat stormwater runoff with a comparably low footprint, and are particularly suitable in dense urban environments (7). SCMs have historically been constructed for pollutants and nutrient reduction from different environments $(9,10)$. Nevertheless, many studies on the impact of SCMs have also evaluated their function for removal of bacteria, in particular filter-based bioretention systems have shown fecal bacteria removal efficiencies between $50 \%$ and $70 \%$ with significant difference between inflow and outflow concentrations $(11,12)$. Pathogenic 
bacteria, viruses and protozoa can be found in runoff $(13,14)$ and are transported to surface waters through sewer overflows, representing one of the major human health risks $(15,16)$. While the microbial load of sewer overflows has gained considerable attention, microbes of traffic area runoff in general are scarcely investigated with only few exceptions. Due to the heavy pollution and harsh conditions, traffic areas and their runoff can be classified as an extreme environment. Early research looked mainly at microbial communities found in sediments of infiltration basins (17), on the effect of de-icing salts $(18,19)$, the biofilm of road gutters $(20)$, or on the denitrification potential of road runoff receiving biofilters (21). More comprehensive analysis on the microbiology of road runoff are missing and most of the microbes and their community functioning in this polluted environment remain unknown, despite we can assume that they will be of relevance for the receiving water bodies (groundwater and surface waters) (22,23). Furthermore, understanding how antibiotic resistance genes (ARGs) are distributed along road runoff treatment processes is important due to their potential public health risk. The location of ARGs on mobile genetic elements, such as integrons (i.e. int/1, sul1) makes the horizontal transfer of antibiotic resistance possible and easy to achieve among bacteria with same or diverse origins. Previous studies assessed the presence of Intl1 in the genome of bacterial isolates from wastewater and drinking water treatment plants $(24,25)$ showing a high possibility of horizontal gene transfer of ARGs within these systems. Therefore, an investigation of these microbial communities can provide insights into adaptations of microbial communities to factors such as $\mathrm{pH}$, contaminants and heavy metals $(26,27)$, and shed light on potential microbial risks.

This study is a pioneer study on the microbial community composition and its anthropogenic signatures in the form of class I integron gene casettes (int/1) of road runoff effluents and the filter materials of two SQIDs along a heavily trafficked urban road in Munich, Germany. We collected water samples for over seven months, and sampled the 
94 filter media of the SQIDs. The aims of this study were to: (I) identify the major taxa of road runoff and treated effluent and (II) identify microbial risk factors associated with the mobile

96

98

100

102

104

\section{MATERIALS AND METHODS}

\subsection{Study site}

In this study we monitored two different SQIDs (D1, D2, Figure S1) from a heavily trafficked road in Munich (Germany, 48 $10^{\prime} 47^{\prime \prime} \mathrm{N} 11^{\circ} 32^{\prime} 25^{\prime \prime} \mathrm{E}$ ) with an annual average daily traffic of 24,000 vehicles per day. Device D1 and D2 are pre-manufactured SQIDs (SediSubstrator XL 600/12, Fränkische Rohrwerke Gebr. Kirchner GmbH \& Co. KG, Germany; Drainfix Clean 300, Hauraton GmbH \& Co. KG, Germany). Both SQIDs were installed at the same time and drained road runoff from catchments in close proximity, which consequently showed the same runoff properties. The main difference between the devices were that D1 used a primary sedimentation stage and downstream media filtration stage using an ironbased filter medium with lignite addition and the filter medium was permanently submerged, while D2 used direct filtration with a carbonate containing sand, which ran dry after each rain event. After the treatment, the water was percolated into the groundwater. The catchment areas of the devices were $1660 \mathrm{~m}^{2}$ for $\mathrm{D} 1$ and $165 \mathrm{~m}^{2}$ for D2.

\subsection{Sampling and characterization}

Water samples before $(n=21)$ and after SQID treatment $(n=20)$ were withdrawn during a seven-month time frame starting from April to October 2019, in order to evaluate different 
seasonal change (spring, $n=19$; summer, $n=13$; autumn, $n=9$ ). Three different types of water samples were collected based on the position of sampling: Influent (I): inflow of road runoff to the SQIDs; Effluent after sedimentation and adsorption (ESA): effluent of SQID D1;

Effluent of Filtration (EF) filtrated water samples of the SQID D2. The samples were withdrawn volume proportionally using automatic samplers (WS 316, WaterSam, Balingen,

24 Germany). Permanent flow measurement using electro-magnetic flow meters (Krohne Optiflux 2300 C or 1300 C, Krohne IFC 300 C, DN250 for D1, DN25 for D2) enabled the volume proportional sampling. Sampling was triggered, if flow exceeded for $1 \mathrm{~min}$ $0.4 \mathrm{~L} /(\mathrm{s} \cdot \mathrm{ha})$ and stopped if flow was below the threshold value for $15 \mathrm{~min}$. Discrete samples (400 mL) were withdrawn after approximately $0.2 \mathrm{~L} / \mathrm{m}^{2}$ runoff volume each. The discrete samples of each sampling point and runoff event were merged in composite samples for further analysis. The number of discrete samples per sampling point and runoff event depended on the runoff volume and ranged from 2 to 62 . The samples were kept in coolers at $4 \pm 1^{\circ} \mathrm{C}$ and transported to the lab within $60 \mathrm{~h}$. Electric conductivity $(\mathrm{EC})$ and $\mathrm{pH}$ of the samples were analyzed following the standard methods $2510 \mathrm{~B}$ and $4500-\mathrm{H}_{+}$, respectively (28). Total concentrations of chromium ( $\mathrm{Cr})$, copper (Cu), nickel (Ni), lead (Pb) and zinc ( $\mathrm{Zn})$ were determined after aqua regia digestion according to EN ISO 15587-1:2002. Cd, Cu, Ni, and $\mathrm{Pb}$ were analyzed using ICP-MS (NexION 300D, Perkin Elmer, Waltham, USA). The other elements were analyzed using ICP-OES (DIN EN ISO 11885, Ultima II, Horiba Jobin

Yvon, Kyoto, Japan). The limits of quantification (LOQs) were 1.0, 0.1, 0.4, 0.1, and $2.0 \mu \mathrm{g} / \mathrm{L}$ for $\mathrm{Cr}, \mathrm{Cu}, \mathrm{Ni}, \mathrm{Pb}$, and $\mathrm{Zn}$, respectively. Dissolved concentrations of $\mathrm{Cr}, \mathrm{Cu}, \mathrm{Ni}, \mathrm{Pb}$, and $\mathrm{Zn}$ 140 were analyzed for a subset of samples after filtration using syringe filter $(0.45 \mu \mathrm{m}, \mathrm{PES}$, VWR International, Darmstadt, Germany). The LOQs of the dissolved $\mathrm{Cr}, \mathrm{Cu}, \mathrm{Ni}, \mathrm{Pb}$, and 
144 Filter material samples (> $500 \mathrm{~g}$ ) were withdrawn from the SQIDs after approximately 2.75 years of operation, labeled FD1 for SQID D1 and FD2 for SQID D2. The surface layer (0$5 \mathrm{~cm}$ ) in flow direction of the filter materials, which commonly contain most of the contaminants (29-31), was sampled using ethanol cleaned plastic spatulae and a stainlesssteel soil sampler. In addition, we took samples for the microbial community analysis in the middle $(5-10 \mathrm{~cm})$ and deepest layer $(10-15 \mathrm{~cm})$ in the flow direction of the filter materials. The content of $\mathrm{Cr}, \mathrm{Cu}, \mathrm{Ni}, \mathrm{Pb}$, and $\mathrm{Zn}$ in the filter media were analyzed after inverse aqua regia digestion adapted from $\mathrm{DIN}$ EN 13346:2001 with a $\mathrm{HNO}_{3}: \mathrm{HCl}$ ratio of 3:1 using the aforementioned ICP-MS and ICP-OES devices. The LOQs of $\mathrm{Cr}, \mathrm{Cu}, \mathrm{Ni}, \mathrm{Pb}, \mathrm{Zn}$ in the filter media were 5.0, 5.0, 2.0,10.0, and $1.0 \mathrm{mg} / \mathrm{kg}$, respectively.

All analysis results for water and filter media samples below LOQ were substituted by the respective $L O Q$ value as a conservative estimate.

To assess the overall pollution level of the water samples, a water pollution index (WPIGFs) was determined based on the German insignificance threshold values for evaluation of locally restricted groundwater pollution (Geringfügigkeitsschwellenwerte, Table S1), which are used to evaluate if a negative anthropogenic effect on groundwater quality is present, following eq. 1. This method is adapted from Bartlett et al., 2012

$$
\mathrm{WPI}_{\mathrm{GFS}}=\sum \frac{\left[\mathrm{C}_{\mathrm{i}}\right] / \mathrm{C}_{\mathrm{i}, \mathrm{GFS}}}{\mathrm{n}}
$$

164 where $\left[\mathrm{C}_{\mathrm{i}}\right]$ is the concentration of the substance i present in the sample, $\mathrm{C}_{\mathrm{i}, \mathrm{GFS}}$ is the minor threshold value of substance $i$, and $n$ is the number of analyzed substances. The heavy metals $\mathrm{Cr}, \mathrm{Cu}, \mathrm{Ni}, \mathrm{Pb}$, and $\mathrm{Zn}$ were considered in this analysis. 


\subsection{DNA Extraction and 16S rRNA Gene Amplicon Sequencing}

Water samples collected from the different devices were centrifuged at 5000 rpm for 10 minutes and the pellets were stored at $-20^{\circ} \mathrm{C}$, while the filter media samples were directly stored at $-20^{\circ} \mathrm{C}$ until DNA extraction. The DNA was extracted using the FastDNA Spin Kit

172 for Soil (MP Biomedicals, Solon, USA), following the manufacturers protocol. The DNA concentration of the individual extracts was quantified by using the dsDNA Broad Range Assay kit (DeNovix, Wilmington, USA), following the manufacturers protocol, then stored at $-80^{\circ} \mathrm{C}$ until sequencing. The $16 \mathrm{~S}$ rRNA gene amplicon sequencing was performed at ZIEL using the primers 341F/806R targeting mainly bacteria (Institute for Food \& Health at Technical University of Munich, Germany). All the data are generated using a MiSeq sequencer (Illumina technology, v3 chemistry) following the protocol of (34)

\subsection{Data Analysis and Quality Control}

All 16S rRNA gene amplicons were processed using the open-source bioinformatic pipeline

DADA2 (version1.14.1, Callahan et al., 2016) for R (version 3.6.0) (36). Demultiplexing and quality filtering were carried out in DADA2 using customized settings (truncLen=c(290,200), trimLeft $=c(14,12), \max N=0, \operatorname{maxEE}=c(2,6))$ after the removal of the primers sequence. Error rates were subsequently estimated from a set of subsampled reads (1 million random reads), and chimeric sequences were identified and removed from the demultiplexed reads. The exact amplicon sequence variants (ASVs) were taxonomically classified with a naïve Bayesian classifier using the Silva v. 138 training set (https://benjineb.github.io/dada2/training.html, accessed August 2020). Negative controls, 
2.5 Quantitative Polymerase Chain Reaction (qPCR)

A quantitative Polymerase Chain Reaction (qPCR) protocol was performed to quantify the number of $16 S$ rRNA and int/1 gene copies within samples. 16S rRNA gene was amplified GTATTACCGCGGCTGCTGG-3' (37). Intl1 was amplified with the int/1 primers from (38).

The qPCR for $16 \mathrm{~S}$ rRNA was carried out with a reaction mixture containing $10.5 \mu \mathrm{L}$ GoTaq® qPCR Master Mix (2X) (Promega, Madison, USA), $0.2 \mu \mathrm{M}$ of each primer, $7.5 \mu \mathrm{L}$ nuclease consisted of $2 \mathrm{~min}$ at $95^{\circ} \mathrm{C}, 40$ cycles with $5 \mathrm{~s}$ at $95^{\circ} \mathrm{C}, 30 \mathrm{~s}$ at $60^{\circ} \mathrm{C}$, while for int/ 1 the program was $4 \mathrm{~min}$ at $95^{\circ} \mathrm{C}, 40$ cycles with $10 \mathrm{sec}$ at $95^{\circ} \mathrm{C}, 45 \mathrm{~s}$ at $64^{\circ} \mathrm{C}$. Both were performed using the CFX96 thermocycler (BioRad, Hercules, USA). Calibration curves for intl1 were obtained using serial dilutions of a purified PCR products (by NGSBeads, Steinbrenner, Wiesenbach, Germany, following the manual) derived from wastewater.

Calibration curves for $16 \mathrm{~S}$ rRNA were obtained by serial dilutions of a linearized plasmid (pGEM-T easy, Invitrogen, Carlsbad, USA) carrying a single amplicon variant. Specificity of PCR reactions was checked by melt curves, and potential false positives were removed. All samples were analyzed in technical duplicates to obtain final copy numbers per sample by averaging.

\subsection{Int/1 gene cassette sequencing}

Genomic DNA from three effluent water and two filter material samples of the devices D1 and D2, was used for characterization of class 1 integron gene cassette arrays (int/1). The cassette arrays of Tn402-associated class 1 integrons were amplified using the primers HS458 and HS459 (39). These primers target the integron recombination site, and the 3' end of the cassette array, which normally terminates in the qacE $\Delta /$ sul1 gene fusion. 
220 Sequencing of HS458/459 PCR products can thus recover resistance determinants. The library collection was carried out with the following cycling program: $94^{\circ} \mathrm{C}$ for 3 min; $94^{\circ} \mathrm{C}$ for $30 \mathrm{~s}, 55^{\circ} \mathrm{C}$ for $30 \mathrm{sec}, 72^{\circ} \mathrm{C} 1 \mathrm{~min} 30 \mathrm{~s}$ for 35 cycles and $72{ }^{\circ} \mathrm{C}$ for $5 \mathrm{~min}$. Amplicons were pooled and sequencing was performed using MinION (Oxford Nanopores

224 Technologies, Oxford, UK) using the LSK-109 library preparation according to the manufacturers recommendations and a Flongle flow cell generating 622,526 reads with the high accuracy basecalling mode (MinKnow version 19.10.1).

MinION fastq reads were converted to FASTA format using pefcon (part of the PETKit,, Bengtsson-Palme, 2012) and translated into all six reading frames using the EMBOSS transeq tool (40), options "-trim -clean -frame 6". Resistance genes were identified using confirmed (44) databases with $70 \%$ identity threshold (options “-id 0.7 -blast6out out.blastp -evalue 0.001 "). Prior to this search, the FARME database was filtered to contain only actual antibiotic resistance protein sequence, following the protocol in (45). A similar approach was taken to identify markers for mobile genetic elements, using the MGEDB as reference (46) (usearch local options “-id 0.7 -blast6out out.blastp -strand both"). The six-frame translations were also scanned against Pfam (47) using HMMER (using defined trusted thresholds, the “--cut_tc" option). All annotations were added to a FARAO annotation database (48). Lists 240 of annotated integron regions were then produced by querying the FARAO database with different criteria.

\subsection{Statistical Analysis}

244 Statistical analysis of the microbial community composition was performed by converting the ASV table produced by DADA2 into phyloseq objects using the "phyloseq" package 
246 (v.1.24.2) in $R(v$ 3.6.0) $(36,49)$. The microbial diversity indices were analyzed using the "vegan" and "betapart" package from CRAN $(50,51)$. The Shannon index was used for the alpha diversity while ASV richness estimate was determined by rarefying the amplicon dataset to the smallest sample (3538). Kruskal-Wallis was used to test significant differences between experimental conditions. Differential abundance analysis of taxa to identify the removal/replacement of microbes before and after the SQIDs was performed by DESeq2 (v 1.29.5) (52). To gain insight about the overall microbial retention exerted by the SQIDs, we partitioned the $\beta$-diversity into two components: turnover ( $\beta$-sim) and nestedness ( $\beta$-ness) (51). Multivariate statistics were investigated with generalized linear models (GLMs) for multivariate abundance data using the mvabund package (53). Predictive models were fitted using "negative.binomial" family, often being appropriate for count data, with the meanvariance function tending to be quadratic rather than linear. Non-metric multi-dimensional Scaling (NMDS) was used to visualize the microbial community composition and how it aligned with different variables (heavy metals, int/1, sample type). The int/1 data were further normalized by the $16 \mathrm{~S}$ rRNA copy numbers. The qPCR data (16S rRNA, int/1) were logtransformed prior to statistical analysis. We used the BioEnv approach (54) to examine the best subset of environmental variables, correlating with community dissimilarities. In addition, to explore the correlation between microbial community's relative abundance, heavy metals, and int/1 gene abundances, Spearman correlations were calculated. To test if the heavy metal could predict the bacterial composition, we assessed the significance of the correlation using the "adonis2" function in vegan (55) (v 3.6.0). The relationship between heavy metals and int/1 gene abundance we tested by a Spearman correlation.

\subsection{Data availability}

270 The sequence data (Microbial community and intl1 amplicon data) is deposited at ENA (https://www.ebi.ac.uk/ena) under the accession number: PRJEB41986. The underlying 
272 ASV and metadata table can be found in the Supplementary Material (Water_Runoff_ASV_Table.csv,Water_Runoff_Metadata.csv,Sand_Filters_ASV_Table.csv ,Sand_Filters_Metadata.csv).

\section{RESULTS}

3.1 Physico-chemical properties of road runoff, effluent of the SQIDs and filter media

As already described for this site by Helmreich et al. (56), the concentrations of $\mathrm{Cr}, \mathrm{Cu}, \mathrm{Ni}$, $\mathrm{Pb}$, and $\mathrm{Zn}$ as well as the pollution level (WPIGFs) of the analyzed road runoff (influent, I) and effluent samples of the two SQIDs (ESA, EF) showed strong seasonal variation with higher values observed in spring (Table 1). The higher EC in the spring samples indicate

the influence of de-icing salt (sodium chloride) applied on-site, which contribute significantly to the toxicity of road runoff (33). As a consequence of the neutral to slightly alkaline $\mathrm{pH}$ of the samples, heavy metals were predominantly found in the particulate phase in the influent of the SQIDs. The dissolved $\mathrm{Pb}$ concentrations were below LOQ, as were half of the dissolved $\mathrm{Cr}$ and $\mathrm{Ni}$ concentrations. Consequently, it was only possible to determine the dissolved fractions of $\mathrm{Cu}$ and $\mathrm{Zn}$, which were in median 18 and $21 \%$. The overall pollution level, as indicated by the WPIGFS, of the SQID effluents was lowered with lowest total heavy metal contamination in EF. In ESA $18 \%$ of $\mathrm{Cu}$ and $38 \%$ of $\mathrm{Zn}$ were dissolved. In EF larger dissolved fractions were observed: $63 \% \mathrm{Cu}$ and $40 \% \mathrm{Zn}$. In the filter material sample FD1 showed higher Ni contents than in FD2, but showed lower values for the residual metals, respectively.

\subsection{Microbial parameters of road runoff and SQID systems}

The investigated SQIDs were colonized by a diverse range of microbial taxa. About 7,538 unique amplicon sequence variants (ASV) were detected for water samples (I, ESA, EF) and 5,599 in filter material FD1 and FD2 (Table 2). The 16S copies as an approximation for 
cell counts ranged in the order of $10^{8}-10^{9}$ copies per $\mathrm{ml}$ water. The copy numbers in the filter material was in the range of $10^{7}$ copies per gram material. The class I integron gene cassette int/1 copy numbers had high numbers in both filter material and water samples. Neither strong seasonal effects nor differences between the filter materials in terms of $16 \mathrm{~S}$ copies were detected.

\subsection{Microbial taxa of road runoff}

In both systems, the most prevalent phyla consisted of Proteobacteria, - mainly composed

by Gammaproteobacteria and Alphaproteobacteria, followed by Actinobacteriota, and Bacteroidota (Fig.2A). The main difference between the two devices was an increased proportion of Campilobacteriota for D1 that had itself established in the intermediate ESA (7\%). At the genus level many genera ranged below $2 \%$ relative abundance (Fig. $2 \mathrm{~B}$ ). Most Acidovorax and Arthrobacter that were found in the influent were still present in ESA. The ESA water samples showed a dominance of Pseudarcobacter (8\%). In contrast to the water samples, the filter media of the SQIDs were clearly distinct (with minor vertical changes between the filter horizons; Figure S2). For both filter media, the most prevalent phyla consisted of Gammaproteobacteria and Alphaproteobacteria, followed by Actinobacteriota, genus level, Hydrogenophaga and Rhodoferax (4.7\% and $4.1 \%$, respectively) were the dominant taxa in FD1 column, while Arenimonas (3.4\%) and Sphingomonas (2.8\%) dominated FD2 (Fig. 2B)

\subsection{Retention of microbes by SQIDs}

By partitioning the $\beta$-diversity into loss of species (nestedness) and species turnover, we could confirm that we mainly see a turnover of taxa (as ASV) between influent and effluent 
of D1 (turnover $=0.81$, nestedness $=0.04$ ) and D2 (turnover $=0.90$, nestedness $=0.02$ ), pointing to rather a replacement of species along the water's flow of the SQIDs, than a species loss along the environmental gradient (Overall nestedness $=0.03$ ). Differential abundances of microbial genera pointed to few differentially enriched genera for D1 and D2 (Figure S3). In D1 few genera showed up, but a high enrichment of C39 (Rhodocyclaceae; log2 fold change of 28.5) was observed. In D2, a stronger removal was detected with 15 different genera with up to $21.2 \log 2$ fold change. On the ASV level, we identified several potential microbial risk factors, i.e., taxa that are derived from animal host systems and may be relevant for human health and hygiene (e.g. Erysipelothrix, Shigella, Escherichia, Table S2). The majority of these taxa were mostly found at very low relative abundances in the 334 road runoff $(<0.08 \%)$. Among the potential bacterial pathogens, the genus Pseudomonas was dominant in all samples followed by Corynebacterium in the effluent ESA.

3.5 Factors that influence the microbial community composition

Multivariate statistics separates the two effluent water samples EF and ESA, and further point to single metals, $\mathrm{pH}$, and int/1 as additional influencing factors (Figure 2, Table S3). Moreover, seasonal changes and heavy metals (as sum of $\mathrm{Cr}, \mathrm{Cu}, \mathrm{Ni}, \mathrm{Pb}$ and $\mathrm{Zn}$ molarity), impacted the species composition of the effluent samples (GLM: LRT $=12395$, LRT $=9350$, $p=0.006$ and $p=0.03$, respectively).

\subsection{The influence of heavy metals on microbial taxa}

346 In order to gain more insight on the role of heavy metals, we preselected the most predictive metals using bioenv, which indicated an influence of $\mathrm{Ni}, \mathrm{Zn}$ and $\mathrm{Cu}$ on the microbial 
int/1 abundance showed linear relationships with the heavy metals concentrations $\mathrm{Ni}, \mathrm{Pb}$, and $\mathrm{Zn}$ with higher explanatory power for $\mathrm{Ni}$ and $\mathrm{Zn}\left(\mathrm{R}^{2}>0.71, \mathrm{p}<0.001\right.$; Figure 3$)$. This was further explored by co-correlating the most abundant 50 genera with, heavy metals, and intl1 (Figure 4). A total of seventeen genera showed positive correlations with the metal concentrations, with Aquabacterium, Hydrogenophaga and Trichococcus associated with almost all the measured metals. Three out of the five heavy metals ( $\mathrm{Ni}, \mathrm{Pb}$ and $\mathrm{Zn}$ ) showed the highest positive association with the relative abundance of genera $\left(R^{2}>50, p<0.05\right)$. On the other hand, Aeromonas, Aquicella, Legionella and Pseudomonas were showing significantly negative correlations to heavy metals.

\subsection{The role of int/1 in facilitating heavy metal resistances}

360 Eleven genera were also co-correlating with intl1 (C39, Dechloromonas, Ferribacterium, Flavobacterium, Hydrogenophaga, Limnohabitans, Polynucleobacter, Pseudarcobacter, Trichococcus and Zoogloea, $R^{2}>0.45 p<0.05$ ). To further test these potential linkages of intl1 and heavy metal resistance, we sequenced parts of the genes that were carried by the class 1 integrons in the systems. In total, 296 of the 622,526 reads from the integrons $(0.05 \%)$ contained 98 different resistance genes. Of these, 82 were metal or biocide resistance genes (BacMet), 7 were clinically relevant antibiotic resistance genes (ResFinder) and 11 were antibiotic resistance genes previously only encountered in functional metagenomics studies (FARME). The most common antibiotic resistance genes were aminoglycoside resistance genes aadA5 (found on 6 integron sequences) and aadA4 370 (3 sequences), and fluoroquinolone efflux pump oqxB (4 sequences). Four other genes (aac(3)-la, $a a c(3)-l b, \operatorname{msr}(D)$ and vat(E)) were found only once. Most of the identified genes were involved in metal resistance, most commonly to heavy metals such as $\mathrm{Pb}, \mathrm{Cd}$ and $\mathrm{Zn}$ (Figure 5). $\mathrm{Cu}$ and $\mathrm{Ag}$ resistance genes constituted around $13 \%$ of the identified genes, while antibiotic resistance genes accounted for $8.6 \%$ of the identified genes in total. Biocide 
resistance genes made up approximately one-third of the identified resistance genes. The most commonly encountered resistance genes (> 6 occurrences) were the metal resistance genes czrA, czcA and silP, the biocide resistance gene qacE, and the efflux pumps mexW and mexl that also facilitate multidrug resistance (Table S4).

\section{DISCUSSION}

The results revealed that SQIDs not only retain heavy metals from road runoff, but also change the microbial community composition, alter the microbial load, and influence the mobile genetic elements. The overall analysis of the road runoff and the SQID samples indicated a predominance of Gammaproteobacteria, Actinobacteriota and Bacteroidota in the water and the respective filters media. These findings are consistent with previous reports, where these phyla have been identified in stormwater runoff as anthropogenic or erosion signatures (57-59). Similarly, the taxa that occurred in the SQID filter materials, like Desulfobacterota, Chloroflexi and Acidobacteriota, were all previously observed in an infiltration basin collecting highway runoff (17). Acidobacteriota are mainly found in low $\mathrm{pH}$ environments (60) tolerating various pollutants such as PCBs, petroleum compounds $(61,62)$ and heavy metals $(63)$. Only few taxa with pathogenic potential were present at low levels, and SQIDs are not designed for microbial retention, but their occurrence in the road runoffs warrants further investigation, in particular when the water treatment selects for mobile genetic elements and when the receiving waters are considered as critical resource.

\subsection{Influence of heavy metals on the microbial community}

Heavy metals with high concentrations in waters or soils show toxic effects to almost all microbes by affecting metabolic functions such as protein synthesis $(64,65)$, thus leading to variations in microbial biomass and diversity (66). Several studies have shown how $\mathrm{Cu}, \mathrm{Zn}$, $\mathrm{Pb}$ and other heavy metals severely inhibited microbial biomass and could cause a reduction 
of microbial $\alpha$-diversity (67). The most common conclusion is that only high concentrations can significantly decrease bacterial biomass, whereas mid-low concentrations of heavy metals can increase microbial biomass and stimulate microbial growth $(68,69)$. Our $\mathrm{pH}$ and 406 metal measurements indicated that large fractions of the heavy metals are not readily bioavailable, nevertheless particulate-bound heavy metals are considered partly bioavailable (70). Anoxic conditions in particular may favor metal reduction as a source of energy, which generally leads to the release of metal ions into the water (e.g., Teiri et al., 408 2016). The prevalence of Desulfobacterota, which are responsible for sulfate reduction processes in stormwater retentions ponds (72), together with Chloroflexi that constitute a substantial proportion of the activated sludge community in wastewater treatment plants (73), point to anoxic processes that may occur in the SQID systems.

\subsection{Heavy metal resistances are linked to int/1}

$414 \mathrm{Ni}$ and $\mathrm{Zn}$, that showed and influence on the microbial community composition are known to induce different resistance mechanisms in bacterial metabolism (74-76). In this context, one interesting case was Arcobacter (and Pseudoarcobacter; Pérez-Cataluña et al., 2018), which was abundant in water and filter material. Arcobacter is known to form biofilms in various pipe surfaces, such as stainless steel, $\mathrm{Cu}$, and plastic, colonizing water distribution systems $(78,79)$. In our case, Pseudoarcobactermainly correlating to Ni and Zn also, showed

a strong correlation with int/1 gene abundance, thus suggesting the selection for bacterial resistance in Pseudoarcobacter. Both, metal and antibiotic resistance are commonly carried on mobile genetic elements. Integrons, in particular, have been recognized as marker for anthropogenic pollution (80). Prior research from different heavy metal polluted scenarios showed the development of resistances due to horizontal gene transfer $(81,82)$, and there have been signs of co-selection of several resistant genes linked to clinically relevant antibiotic resistance (83). For example, resistance to $\mathrm{As}, \mathrm{Mn}, \mathrm{Co}, \mathrm{Cu}, \mathrm{Ag}, \mathrm{Zn}$, Ciprofloxacin, 
$\beta$ - lactams, chloramphenicol and tetracycline is achieved by reduction in membrane permeability $(84,85)$. Similarly $\mathrm{Cu}, \mathrm{Co}, \mathrm{Zn}, \mathrm{Cd}$, tetracycline, chloramphenicol and $\beta$ - lactams resistance is achieved through rapid efflux of metal or antibiotic $(86,87)$. Therefore, heavy metals have potential to represent extended selection pressure for development of antibiotic resistance in microorganisms (88), and the transfer of these resistant bacteria in the environment may pose potential risks to human health (89).

The int/1 gene cassette analysis highlighted the presence of heavy metal resistances in these microbial communities, and the abundance of int/1 in the filter media, compared to the influent, suggests a strong selection pressure that aligns with a significant rate of horizontal gene transfer taking place in the systems. The amount of bacteria carrying class 1 integrons is consistent with data reported in polluted water systems like WWTPs (90). However, while previous research, normally described high removal rates of bacteria carrying class 1 integrons (55\%) after treatment process (90), consistent with our findings, few studies has reported an increase in the abundance of the int/1 gene during the wastewater treatment $(91,92)$. The variation of results observed among studies may be attributed to several factors such as selected resistant bacterial taxa, the climat and population conditions, occurrence of rain events before sampling as well as organic loading, $\mathrm{pH}$ and temperature. Horizontal gene transfer plays an important role in the evolution, diversity and recombination of multidrug resistant strains $(93,94)$. The class 1 integron has been associated with the presence of metal resistance genes (MRGs) and antibiotic resistance genes (ARGs) $(95,96)$. Our data suggests that SQIDs could be a high-risk environment for resistance development, similar to other hotspots, like manure, sewage and municipal solid waste (97-99). Furthermore, the presence of different resistance genes (e.g. czrA, czcA and silP), including the high 452 proportion of multidrug resistance genes (e.g. mexW, $(100,101))$ as well as the strong 
454

456

458

460

\section{ACKNOWLEDGEMENT}

We would like to thank Heidrun Mayrhofer and Hubert Moosrainer for technical assistance. MRGs and ARGs within road runoff drainage systems. While no typical antibiotic treatment related resistance genes (sul1, ampC, etc.) were identified, they may be present on other mobile genetic elements not targeted in this study.

\subsection{Limitations and future directions}

This study provides a first deeper description of road runoff microbial communities and contributes to our understanding of their potential environmental impact on the receiving water bodies. As a pioneer study, our study design was limited to two SQIDs and we could only monitor three seasons. Thus, we could not investigate if there are further effects by e.g. higher amounts of de-icing salts in winter, which potentially enhance mobility and bioavailability of the present heavy metals $(33,102,103)$. Furthermore, we did not consider other systems such as infiltration basins or sand filters, and it remains an open question if our results are transferable to other road runoff drainage systems. However, it is obvious that runoff from a highly trafficked urban road carries a high microbial load with dominant signs of anthropogenic pollution. This comes with a relatively high risk related to the cycling of resistance genes and thus microbial risk mitigation practices should be considered in the future. Recently, it has become clear that microbes are critically linked to our changing environment, and that they have to be included in future policies (104). Future studies are therefore encouraged to assess the risks of discharge of microbes and their resistance genes from SQIDs and other SCMs into receiving environments.

\footnotetext{
$\mathrm{RL}$ acknowledges the International PhD Programme "Environment, Resources and
}

positive correlations to heavy metals, suggest that integrons contribute to the spread of Sustainable Development" scholarship (\#Parthenope University of Naples), monitoring of 
478 the SQIDs by BH and SR was funded by the Bavarian Environment Agency (AZ: 67-027096505/2016 and AZ: 67-0270-25598/2019). JBP was supported by the Sahlgrenska 00299) under the frame of JPI AMR (EMBARK; JPIAMR2019-109), and the Centre for Antibiotic Resistance Research at the University of Gothenburg (CARe). CW was financially supported by TUM Junior Fellowship and the DFG project (WU 890/2-1). We would like to thank Dr. Klaus Neuhaus of the ZIEL Core Facility Microbiome, Technical University of Munich, Freising, Germany, for sequencing.

\section{COMPETING INTERESTS}

M.Sc. Liguori, Dr. Wurzbacher, and Dr. Bengtsson-Palme declare no competing interests. M.Sc. Rommel and Dr. Helmreich informed the Bavarian Environment Agency, as well as the SQID companies FRÄNKISCHE Rohrwerke and Hauraton on the content of this article prior to submission.

\section{REFERENCES}

1. Adachi K, Tainosho Y. Characterization of heavy metal particles embedded in tire dust. Environ Int. 2004;

2. Ball JE, Jenks R, Aubourg D. An assessment of the availability of pollutant constituents on road surfaces. Sci Total Environ. 1998;

496 3. Legret M, Pagotto C. Evaluation of pollutant loadings in the runoff waters from a major rural highway. In: Science of the Total Environment. 1999.

498 4. Eriksson E, Baun A, Mikkelsen PS, Ledin A. Chemical hazard identification and assessment tool for evaluation of stormwater priority pollutants. Water Sci Technol. 2005; 
6. Markiewicz A, Björklund K, Eriksson E, Kalmykova Y, Strömvall AM, Siopi A. Emissions of organic pollutants from traffic and roads: Priority pollutants selection and substance flow analysis. Sci Total Environ. 2017;

7. Dierkes C, Lucke T, Helmreich B. General technical approvals for decentralised sustainable urban drainage systems (SUDS)-the current situation in Germany. Sustain. 2015;

8. Lucke T, Nichols P, Shaver E, Lenhart J, Welker A, Huber M. Pathways for the Evaluation of Stormwater Quality Improvement Devices - the Experience of Six Countries. Clean - Soil, Air, Water. 2017.

9. Huber M, Welker A, Dierschke M, Drewes JE, Helmreich B. A novel test method to determine the filter material service life of decentralized systems treating runoff from traffic areas. J Environ Manage. 2016;

10. Hilliges R, Schriewer A, Helmreich B. A three-stage treatment system for highly polluted urban road runoff. J Environ Manage. 2013;

11. Hathaway JM, Hunt WF, Jadlocki S. Indicator bacteria removal in storm-water best management practices in charlotte, north carolina. J Environ Eng. 2009;

12. Pennington SR, Kaplowitz MD, Witter SG. Reexamining best management practices for improving water quality in urban watersheds. J Am Water Resour Assoc. 2003;

13. Ahmed W, Hamilton K, Toze S, Cook S, Page D. A review on microbial contaminants in stormwater runoff and outfalls: Potential health risks and mitigation strategies. Science of the Total Environment. 2019.

14. Pandey PK, Kass PH, Soupir ML, Biswas S, Singh VP. Contamination of water resources by pathogenic bacteria. AMB Express. 2014; 
16. Ma Y, Egodawatta P, McGree J, Liu A, Goonetilleke A. Human health risk assessment of heavy metals in urban stormwater. Sci Total Environ. 2016;

17. Rotaru C, Woodard TL, Choi S, Nevin KP. Spatial Heterogeneity of Bacterial Communities in Sediments from an Infiltration Basin Receiving Highway Runoff. Microb Ecol. 2012;

18. Ostendorf DW, Palmer RN, Hinlein ES. Seasonally varying highway de-icing agent contamination in a groundwater plume from an infiltration basin. Hydrol Res. 2009;

19. Ostendorf DW, Rotaru C, Hinlein ES. Steady Groundwater Transport of Highway Deicing Agent Constituents from an Infiltration Basin. J Irrig Drain Eng. 2008;

20. Hervé V, Lopez PJ. Analysis of interdomain taxonomic patterns in urban street mats. Environ Microbiol. 2020;

21. Luo Y, Yue X, Duan Y, Zhou A, Gao Y, Zhang X. A bilayer media bioretention system for enhanced nitrogen removal from road runoff. Sci Total Environ. 2020;

22. Lee S, Suits M, Wituszynski D, Winston R, Martin J, Lee J. Residential urban stormwater runoff: A comprehensive profile of microbiome and antibiotic resistance. Sci Total Environ. 2020;

23. Scharping RJ, Garey JR. Relationship between aquifer biofilms and unattached microbial indicators of urban groundwater contamination. Mol Ecol. 2020;

24. Allen HK, Donato J, Wang HH, Cloud-Hansen KA, Davies J, Handelsman J. Call of the wild: antibiotic resistance genes in natural environments. Nat Rev Microbiol. 2010 Apr;8(4):251-9.

25. Lu J, Tian Z, Yu J, Yang M, Zhang Y. Distribution and Abundance of Antibiotic Resistance Genes in Sand Settling Reservoirs and Drinking Water Treatment Plants across the Yellow River, China. Vol. 10, Water . 2018.

26. Kaevska M, Videnska P, Sedlar K, Slana I. Seasonal changes in microbial community composition in river water studied using 454-pyrosequencing. Springerplus. 2016; 
27. Liao H, Chapman SJ, Li Y, Yao H. Dynamics of microbial biomass and community composition after short-term water status change in Chinese paddy soils. Environ Sci Pollut Res. 2018;

28. Bruno L. Standard Methods for the Examination of Water and Wastewater , 23rd Edition. Journal of Chemical Information and Modeling. 2017.

29. Hatt BE, Fletcher TD, Deletic A. Hydraulic and pollutant removal performance of fine media stormwater filtration systems. Environ Sci Technol. 2008;

30. Muthanna TM, Viklander M, Blecken G, Thorolfsson ST. Snowmelt pollutant removal in bioretention areas. Water Res. 2007;

31. Al-Ameri M, Hatt B, Le Coustumer S, Fletcher T, Payne E, Deletic A. Accumulation of heavy metals in stormwater bioretention media: A field study of temporal and spatial variation. J Hydrol. 2018;

32. Dieter HH, Frank D, Gihr R, Konietzka R, Moll B, Stockerl R, et al. Ableitung von Geringfügigkeitsschwellenwerten für das Grundwasser -- Aktualisierte und überarbeitete Fassung. Lawa [Internet]. 2016;28. Available from: www.lawa.de

33. Bartlett AJ, Rochfort Q, Brown LR, Marsalek J. Causes of toxicity to Hyalella azteca in a stormwater management facility receiving highway runoff and snowmelt. Part II: Salts, nutrients, and water quality. Sci Total Environ. 2012;

34. Reitmeier S, Kiessling S, Neuhaus K, Haller D. Comparing Circadian Rhythmicity in the Human Gut Microbiome. STAR Protoc [Internet]. 2020;1(3):100148. Available from: https://www.sciencedirect.com/science/article/pii/S2666166720301350

35. Callahan BJ, McMurdie PJ, Rosen MJ, Han AW, Johnson AJA, Holmes SP. DADA2: High-resolution sample inference from Illumina amplicon data. Nat Methods. 2016;

570 36. R Development Core Team R. R: A Language and Environment for Statistical Computing. R Foundation for Statistical Computing. 2011. 
38. Barraud O, Baclet MC, Denis F, Ploy MC. Quantitative multiplex real-time PCR for detecting class 1, 2 and 3 integrons. J Antimicrob Chemother. 2010;

39. Holmes AJ, Holley MP, Mahon A, Nield B, Gillings M, Stokes HW. Recombination activity of a distinctive integron-gene cassette system associated with Pseudomonas stutzeri populations in soil. J Bacteriol. 2003;

40. Rice P, Longden L, Bleasby A. EMBOSS: The European Molecular Biology Open Software Suite. Trends in Genetics. 2000.

41. Edgar RC. Search and clustering orders of magnitude faster than BLAST. Bioinformatics. 2010;

42. Zankari E, Hasman $\mathrm{H}$, Cosentino S, Vestergaard M, Rasmussen S, Lund O, et al. Identification of acquired antimicrobial resistance genes. J Antimicrob Chemother. 2012;

43. Wallace JC, Port JA, Smith MN, Faustman EM. FARME DB: A functional antibiotic resistance element database. Database. 2017;

44. Pal C, Bengtsson-Palme J, Rensing C, Kristiansson E, Larsson DGJ. BacMet: Antibacterial biocide and metal resistance genes database. Nucleic Acids Research. 2014.

45. Bengtsson-Palme J. The diversity of uncharacterized antibiotic resistance genes can be predicted from known gene variants-but not always. Microbiome. 2018;

46. Pärnänen K, Karkman A, Hultman J, Lyra C, Bengtsson-Palme J, Larsson DGJ, et al. Maternal gut and breast milk microbiota affect infant gut antibiotic resistome and mobile genetic elements. Nat Commun. 2018;

47. El-Gebali S, Mistry J, Bateman A, Eddy SR, Luciani A, Potter SC, et al. The Pfam protein families database in 2019. Nucleic Acids Res. 2019;

48. Hammarén R, Pal C, Bengtsson-Palme J. FARAO: The flexible all-round annotation organizer. 
49. McMurdie PJ, Holmes S. Phyloseq: An R Package for Reproducible Interactive Analysis and Graphics of Microbiome Census Data. PLoS One. 2013;

50. Oksanen J, Blanchet FG, Kindt R, Legendre P, Minchin PR, O’Hara RB. Package vegan. R Packag ver. 2013; 2012;

52. Love MI, Huber W, Anders S. Moderated estimation of fold change and dispersion for RNA-seq data with DESeq2. Genome Biol. 2014;

53. Wang Y, Naumann U, Wright ST, Warton DI. Mvabund- an R package for model-based analysis of multivariate abundance data. Methods Ecol Evol. 2012;

54. Clarke KR, Ainsworth M. A method of linking multivariate community structure to environmental variables. Mar Ecol Prog Ser. 1993;

55. Anderson MJ. A new method for non-parametric multivariate analysis of variance. Austral Ecol. 2001;

56. Helmreich B, Hilliges R, Schriewer A, Horn H. Runoff pollutants of a highly trafficked urban road Correlation analysis and seasonal influences. Chemosphere. 2010;

57. Leung HD, Chen G, Sharma K. Effect of detached/re-suspended solids from sewer sediment on the sewage phase bacterial activity. Water Sci Technol a J Int Assoc Water Pollut Res. 2005;52(3):14752.

58. Shanks OC, Newton RJ, Kelty CA, Huse SM, Sogin ML, McLellan SL. Comparison of the microbial community structures of untreated wastewaters from different geographic locales. Appl Environ Microbiol. 2013;

59. McLellan SL, Fisher JC, Newton RJ. The microbiome of urban waters. International Microbiology. 2015. 
60. Lauber CL, Hamady M, Knight R, Fierer N. Pyrosequencing-based assessment of soil pH as a predictor

61. Abed RMM, Safi NMD, Köster J, De Beer D, El-Nahhal Y, Rullkötter J, et al. Microbial diversity of a heavily polluted microbial mat and its community changes following degradation of petroleum compounds. Appl Environ Microbiol. 2002;

62. Sánchez-Peinado M del M, González-López J, Martínez-Toledo MV, Pozo C, Rodelas B. Influence of linear alkylbenzene sulfonate (LAS) on the structure of Alphaproteobacteria, Actinobacteria, and Acidobacteria communities in a soil microcosm. Environ Sci Pollut Res. 2010;

63. Gremion F, Chatzinotas A, Harms H. Comparative 16S rDNA and 16S rRNA sequence analysis indicates that Actinobacteria might be a dominant part of the metabolically active bacteria in heavy metal-contaminated bulk and rhizosphere soil. Environ Microbiol. 2003;

64. Tang J, Zhang J, Ren L, Zhou Y, Gao J, Luo L, et al. Diagnosis of soil contamination using microbiological indices: A review on heavy metal pollution. Journal of Environmental Management. 2019.

65. Kandeler E, Tscherko D, Bruce KD, Stemmer M, Hobbs PJ, Bardgett RD, et al. Structure and function of the soil microbial community in microhabitats of a heavy metal polluted soil. Biol Fertil Soils. 2000;

66. Kaurin A, Cernilogar Z, Lestan D. Revitalisation of metal-contaminated, EDTA-washed soil by addition of unpolluted soil, compost and biochar: Effects on soil enzyme activity, microbial community composition and abundance. Chemosphere. 2018;

67. Kandeler E, Kampichler C, Horak O. Influence of heavy metals on the functional diversity of soil microbial communities. Biol Fertil Soils. 1996;

68. Fließbach A, Sarig S, Steinberger Y. Effects of water pulses and climatic conditions on microbial biomass kinetics and microbial activity in a yermosol of the central negev. Arid Soil Res Rehabil. 
646 69. Chander K, Brookes PC, Harding SA. Microbial biomass dynamics following addition of metalenriched sewage sludges to a sandy loam. Soil Biol Biochem. 1995;

648 70. Zhang J, Hua P, Krebs P. The build-up dynamic and chemical fractionation of $\mathrm{Cu}, \mathrm{Zn}$ and $\mathrm{Cd}$ in roaddeposited sediment. Sci Total Environ. 2015;

650 71. Teiri H, Rezaei M, Nazmara S, Hajizadeh Y. Sulphate reduction and zinc precipitation from wastewater by sulphate-reducing bacteria in an anaerobic moving-liquid/static-bed bioreactor. Desalin Water Treat [Internet]. 2016 Nov 13;57(53):25617-26. Available from: https://doi.org/10.1080/19443994.2016.1153983

72. D'Aoust PM, Pick FR, Wang R, Poulain A, Rennie C, Chen L, et al. Sulfide production kinetics and model of Stormwater retention ponds. Water Sci Technol. 2018;

73. Zhang B, Xu X, Zhu L. Structure and function of the microbial consortia of activated sludge in typical municipal wastewater treatment plants in winter. Sci Rep. 2017;

74. Schmidt T, Schlegel HG. Nickel and cobalt resistance of various bacteria isolated from soil and highly polluted domestic and industrial wastes. FEMS Microbiol Lett. 1989;

75. Alboghobeish H, Tahmourespour A, Doudi M. The study of Nickel Resistant Bacteria (NiRB) isolated from wastewaters polluted with different industrial sources. J Environ Heal Sci Eng. 2014;

76. Nies DH. Resistance to cadmium, cobalt, zinc, and nickel in microbes. Plasmid. 1992;

77. Pérez-Cataluña A, Salas-Massó N, Diéguez AL, Balboa S, Lema A, Romalde JL, et al. Revisiting the taxonomy of the genus arcobacter: Getting order from the chaos. Front Microbiol. 2018;

78. Assanta MA, Roy D, Lemay MJ, Montpetit D. Attachment of Arcobacter butzleri, a new waterborne pathogen, to water distribution pipe surfaces. J Food Prot. 2002;

79. Cervenka L, Kristlova J, Peskova I, Vytrasova J, Pejchalova M, Brozkova I. Persistence of Arcobacter butzleri CCUG 30484 on plastic, stainless steel and glass surfaces. Brazilian J Microbiol. 2008;

80. Gillings MR, Gaze WH, Pruden A, Smalla K, Tiedje JM, Zhu YG. Using the class 1 integron-integrase 
gene as a proxy for anthropogenic pollution. ISME J. 2015;

81. Rehman A, Anjum MS. Multiple metal tolerance and biosorption of cadmium by Candida tropicalis isolated from industrial effluents: Glutathione as detoxifying agent. In: Environmental Monitoring and Assessment. 2011.

82. Zafar S, Aqil F, Ahmad I. Metal tolerance and biosorption potential of filamentous fungi isolated from metal contaminated agricultural soil. Bioresour Technol. 2007;

83. Pal C, Bengtsson-Palme J, Kristiansson E, Larsson DGJ. Co-occurrence of resistance genes to antibiotics, biocides and metals reveals novel insights into their co-selection potential. BMC Genomics. 2015;

84. Silver S, Phung LT. Bacterial heavy metal resistance: New surprises. Annual Review of Microbiology. 1996.

85. Ruiz N, Montero T, Hernandez-Borrell J, Viñas M. The role of Serratia marcescens porins in antibiotic resistance. Microb Drug Resist. 2003;

86. Nies DH. Efflux-mediated heavy metal resistance in prokaryotes. FEMS Microbiology Reviews. 2003.

87. Levy SB. Active efflux, a common mechanism for biocide and antibiotic resistance. In: Journal of Applied Microbiology Symposium Supplement. 2002.

88. Stepanauskas R, Glenn TC, Jagoe CH, Tuckfield RC, Lindell AH, McArthur J V. Elevated microbial tolerance to metals and antibiotics in metal-contaminated industrial environments. Environ Sci Technol. 2005;

89. Bengtsson-Palme J, Kristiansson E, Larsson DGJ. Environmental factors influencing the development and spread of antibiotic resistance. FEMS Microbiology Reviews. 2018.

90. Paiva MC, Ávila MP, Reis MP, Costa PS, Nardi RMD, Nascimento AMA. The Microbiota and Abundance of the Class 1 Integron-Integrase Gene in Tropical Sewage Treatment Plant Influent and Activated Sludge. PLoS One [Internet]. 2015 Jun 26;10(6):e0131532. Available from: 
https://doi.org/10.1371/journal.pone.0131532

91. Stalder T, Barraud O, Jové T, Casellas M, Gaschet M, Dagot C, et al. Quantitative and qualitative impact of hospital effluent on dissemination of the integron pool. ISME J [Internet]. 2014;8(4):76877. Available from: https://doi.org/10.1038/ismej.2013.189

92. LaPara TM, Burch TR, McNamara PJ, Tan DT, Yan M, Eichmiller JJ. Tertiary-treated municipal wastewater is a significant point source of antibiotic resistance genes into Duluth-Superior Harbor. genes in prokaryotic genomes. Nat Genet. 2004;

94. Thomas CM, Nielsen KM. Mechanisms of, and barriers to, horizontal gene transfer between bacteria. Nature Reviews Microbiology. 2005.

95. Li LG, Xia Y, Zhang T. Co-occurrence of antibiotic and metal resistance genes revealed in complete genome collection. ISME J. 2017;

96. Stokes HW, Hall RM. A novel family of potentially mobile DNA elements encoding site-specific geneintegration functions: integrons. Mol Microbiol. 1989;

97. He LY, Liu YS, Su HC, Zhao JL, Liu SS, Chen J, et al. Dissemination of antibiotic resistance genes in representative broiler feedlots environments: Identification of indicator ARGs and correlations with environmental variables. Environ Sci Technol. 2014;

98. Su JQ, Wei B, Ou-Yang WY, Huang FY, Zhao Y, Xu HJ, et al. Antibiotic Resistome and Its Association with Bacterial Communities during Sewage Sludge Composting. Environ Sci Technol. 2015;

714 99. Wang P, Wu D, You X, Li W, Xie B. Distribution of antibiotics, metals and antibiotic resistance genes during landfilling process in major municipal solid waste landfills. Environ Pollut. 2019;

716 100. Nikaido H. Multidrug resistance in bacteria. Annual Review of Biochemistry. 2009.

101. Chakraborty AK. Multi-Drug Resistant Genes in Bacteria and 21st Century Problems Associated with 
Antibiotic Therapy. Biotechnol An Indian J. 2016;

102. Schuler MS, Relyea RA. A Review of the Combined Threats of Road Salts and Heavy Metals to Freshwater Systems. BioScience. 2018.

103. Acosta JA, Jansen B, Kalbitz K, Faz A, Martínez-Martínez S. Salinity increases mobility of heavy metals in soils. Chemosphere. 2011;

104. Cavicchioli R, Ripple WJ, Timmis KN, Azam F, Bakken LR, Baylis M, et al. Scientists' warning to humanity: microorganisms and climate change. Nature Reviews Microbiology. 2019. 


\section{Tables}

Table 1. Chemical analysis of the water and filter media samples, reported as median $(25 \%-75 \%)$; total concentrations of $\mathrm{Cr}$, $\mathrm{Cu}, \mathrm{Ni}, \mathrm{Pb}$, and $\mathrm{Zn}$ are presented. EC: electric conductivity, and $\mathrm{WPI}_{\mathrm{GFS}}$ : water pollution index. The $\mathrm{WPI}_{\mathrm{GFS}}$ was added to summarize the contamination level of the samples. I: Influent; ESA: Effluent of device D1; FD1: Filter material of D1; FD2: filter material of D2; EF: Effluent of device D2.

\begin{tabular}{|c|c|c|c|c|c|c|c|c|c|c|c|}
\hline & Variable & Category & $\begin{array}{l}\text { Sample } \\
\text { size }\end{array}$ & $\begin{array}{c}\mathrm{pH} \\
(-)\end{array}$ & $\begin{array}{c}E C \\
(\mu \mathrm{S} / \mathrm{cm})\end{array}$ & $\begin{array}{c}\mathrm{Cr} \\
(\mu \mathrm{g} / \mathrm{L})\end{array}$ & $\begin{array}{c}\mathrm{Cu} \\
(\mu \mathrm{g} / \mathrm{L})\end{array}$ & $\underset{(\mu \mathrm{g} / \mathrm{L})}{\mathrm{Ni}}$ & $\begin{array}{c}\mathrm{Pb} \\
(\mu \mathrm{g} / \mathrm{L})\end{array}$ & $\begin{array}{c}\mathrm{Zn} \\
(\mu \mathrm{g} / \mathrm{L})\end{array}$ & $\begin{array}{c}\mathrm{WPI}_{\mathrm{GFS}} \\
(-)\end{array}$ \\
\hline \multirow{9}{*}{ Water } & \multirow{3}{*}{$\begin{array}{l}\text { Sampling } \\
\text { position }\end{array}$} & I & 21 & $\begin{array}{c}7.7 \\
(7.5-7.9)\end{array}$ & $\begin{array}{c}85.9 \\
(73.2-120)\end{array}$ & $\begin{array}{c}7.6 \\
(1.3-23.6)^{b}\end{array}$ & $\begin{array}{c}56.2 \\
(44.0-102)\end{array}$ & $\begin{array}{c}5.9 \\
(3.2-8.6)\end{array}$ & $\begin{array}{c}4 . \\
(2.0-9.7)\end{array}$ & $\begin{array}{c}150 \\
(98.1-300)\end{array}$ & $\begin{array}{c}3.6 \\
(2.6-8.3)\end{array}$ \\
\hline & & $E S A$ & 12 & $\begin{array}{c}7.6 \\
(7.5-7.7)\end{array}$ & $\begin{array}{c}176 \\
(127-278)\end{array}$ & $\begin{array}{c}8.2 \\
(1.0-11.0)^{b}\end{array}$ & $\begin{array}{c}47.9 \\
(25.2-77.8)\end{array}$ & $\begin{array}{c}5.5 \\
(3.9-6.8)\end{array}$ & $\begin{array}{c}2.9 \\
(1.3-6.4)\end{array}$ & $\begin{array}{c}134 \\
(87-216)\end{array}$ & $\begin{array}{c}3.2 \\
(1.6-6.7)\end{array}$ \\
\hline & & $E F$ & 8 & $\begin{array}{c}7.7 \\
(7.7-7.8)\end{array}$ & $\begin{array}{c}168 \\
(129-174)\end{array}$ & $\begin{array}{c}3.8 \\
(1.0-6.5)^{\mathrm{b}}\end{array}$ & $\begin{array}{c}40.1 \\
(23.2-44.6)\end{array}$ & $\begin{array}{c}2.8 \\
(2.0-3.3)\end{array}$ & $\begin{array}{c}1.2 \\
(0.5-2.2)\end{array}$ & $\begin{array}{c}45.3 \\
(33.9-61.9)\end{array}$ & $\begin{array}{c}2.1 \\
(1.6-2.6)\end{array}$ \\
\hline & \multirow{3}{*}{$\begin{array}{l}\text { Season } \\
\text { (influent, I) }\end{array}$} & Spring & 9 & $\begin{array}{c}7.7 \\
(7.5-7.8)\end{array}$ & $\begin{array}{c}120 \\
(112-140)\end{array}$ & $\begin{array}{c}14.8 \\
(1.0-28.0)^{b}\end{array}$ & $\begin{array}{c}99.4 \\
(44.0-144)\end{array}$ & $\begin{array}{c}7.9 \\
(3.2- \\
10.8)\end{array}$ & $\begin{array}{c}6.7 \\
(1.8-12.3)\end{array}$ & $\begin{array}{c}335 \\
(98.1-424)\end{array}$ & $\begin{array}{c}7.0 \\
(2.6-10.9)\end{array}$ \\
\hline & & Summer & 7 & $\begin{array}{c}7.9 \\
(7.4-8.1)\end{array}$ & $\begin{array}{c}79.2 \\
(70.0-99.7)\end{array}$ & $\begin{array}{c}7.6 \\
(3.7-20.9)^{b}\end{array}$ & $\begin{array}{c}56.2 \\
(52.2-85.8)\end{array}$ & $\begin{array}{c}4.6 \\
(3.8-6.1)\end{array}$ & $\begin{array}{c}4.5 \\
(3.4-8.6)\end{array}$ & $\begin{array}{c}150 \\
(145-234)\end{array}$ & $\begin{array}{c}3.6 \\
(3.2-6.8)\end{array}$ \\
\hline & & Autumn & 5 & $\begin{array}{c}7.5 \\
(7.4-7.7)\end{array}$ & $\begin{array}{c}73.2 \\
(58.6-74.8) \\
\end{array}$ & $\begin{array}{c}5.3 \\
(1.2-19.3)^{b}\end{array}$ & $\begin{array}{c}52.2 \\
(20.3-102) \\
\end{array}$ & $\begin{array}{c}6.6 \\
(2.5-8.6) \\
\end{array}$ & $\begin{array}{c}4.0 \\
(1.8-7.5)\end{array}$ & $\begin{array}{c}122 \\
(63.0-209) \\
\end{array}$ & $\begin{array}{c}3.5 \\
(1.4-7.8) \\
\end{array}$ \\
\hline & \multirow{3}{*}{$\begin{array}{l}\text { Season } \\
\text { (effluent, } \\
\text { ESA and } \\
E F)\end{array}$} & Spring & 10 & $\begin{array}{c}7.7 \\
(7.6-7.8)\end{array}$ & $\begin{array}{c}204 \\
(150-374)\end{array}$ & $\begin{array}{c}6.6 \\
(1.0-9.0)^{\mathrm{b}}\end{array}$ & $\begin{array}{c}41.2 \\
(24.6-88.5)\end{array}$ & $\begin{array}{c}4.1 \\
(2.3-5.7)\end{array}$ & $\begin{array}{c}2.5 \\
(1.1-5.3)\end{array}$ & $\begin{array}{c}101 \\
(68.4-228)\end{array}$ & $\begin{array}{c}2.9 \\
(1.5-6.0)\end{array}$ \\
\hline & & Summer & 6 & $\begin{array}{c}7.8 \\
(7.6-7.9)\end{array}$ & $\begin{array}{c}153 \\
(106-176)\end{array}$ & $\begin{array}{c}5.2 \\
(1.1-9.8)^{b}\end{array}$ & $\begin{array}{c}43.5 \\
(31.4-49.1)\end{array}$ & $\begin{array}{c}3.1 \\
(2.7-4.5)\end{array}$ & $\begin{array}{c}1.9 \\
(1.2-2.7)\end{array}$ & $\begin{array}{c}66.1 \\
(40.7-109)\end{array}$ & $\begin{array}{c}2.3 \\
(2.0-2.8)\end{array}$ \\
\hline & & Autumn & 4 & $\begin{array}{c}7.4 \\
(7.2-7.6)\end{array}$ & $\begin{array}{c}155 \\
(119-176)\end{array}$ & $\begin{array}{c}3.5 \\
(1.0-6.6)^{b}\end{array}$ & $\begin{array}{c}33.4 \\
(19.5-49.7) \\
\end{array}$ & $\begin{array}{c}5.0 \\
(3.4-6.8)\end{array}$ & $\begin{array}{c}1.7 \\
(1.2-2.8)\end{array}$ & $\begin{array}{c}74.1 \\
(54.6-105) \\
\end{array}$ & $\begin{array}{c}2.1 \\
(1.4-3.1)\end{array}$ \\
\hline & & & & & & $\begin{array}{c}\mathrm{Cr}^{\mathrm{a}} \\
(\mathrm{mg} / \mathrm{kg})\end{array}$ & $\begin{array}{c}\mathrm{Cu}^{\mathrm{a}} \\
(\mathrm{mg} / \mathrm{kg})\end{array}$ & $\begin{array}{c}\mathrm{Ni}^{\mathrm{a}} \\
(\mathrm{mg} / \mathrm{kg})\end{array}$ & $\begin{array}{c}\mathrm{Pb}^{\mathrm{a}} \\
(\mathrm{mg} / \mathrm{kg})\end{array}$ & $\begin{array}{c}\mathrm{Zn}^{\mathrm{a}} \\
(\mathrm{mg} / \mathrm{kg})\end{array}$ & \\
\hline \multirow{2}{*}{$\begin{array}{l}\text { Filter } \\
\text { media }\end{array}$} & & $F D 1$ & 2 & & & $7.5^{\mathrm{b}}$ & 32.9 & 42.0 & $<10$ & 274 & \\
\hline & & FD2 & 2 & & & 22.4 & 41.1 & 11.7 & $<10$ & 333 & \\
\hline
\end{tabular}

${ }^{a}$ mean of duplicate, ${ }^{b}$ contains value below limit of quantification (LOQ), which was substituted by the value of the LOQ 
Table 2. Water and filter media samples characteristics and statistical analysis for the different samples. I: Influent; ESA: Effluent of device D1; FD1: Filter material of D1; FD2: filter material of D2; EF: Effluent of device D2.

\begin{tabular}{|c|c|c|c|c|c|c|c|}
\hline & Variable & Category & Sample size & ASV richness & Shannon index & $\begin{array}{c}16 \mathrm{~S} \\
\text { (copies } \mathrm{x} \mathrm{ml} \text { ) }\end{array}$ & $\begin{array}{c}\text { Intl1 } \\
\text { (copies X ml) }\end{array}$ \\
\hline \multirow{9}{*}{ Water } & \multirow{3}{*}{ Sampling position } & I & 21 & 2601 & $4.92 \pm 0.3$ & $1.75 \times 10^{9} \pm 1.57$ & $2.04 \times 10^{4} \pm 5.11$ \\
\hline & & $E S A$ & 12 & 1927 & $4.72 \pm 0.6$ & $2.73 \times 10^{9} \pm 2.73$ & $6.43 \times 10^{4} \pm 10.0$ \\
\hline & & $E F$ & 8 & 2259 & $5.32 \pm 0.4$ & $7.44 \times 10^{8} \pm 10.0$ & $5.01 \times 10^{3} \pm 9.96$ \\
\hline & \multirow{3}{*}{$\begin{array}{l}\text { Season } \\
\text { (influent, I) }\end{array}$} & Spring & 9 & 1280 & $4.8 \pm 0.4$ & $2.31 \times 10^{9} \pm 2.01$ & $3.73 \times 10^{4} \pm 7.57$ \\
\hline & & Summer & 7 & 1469 & $5.1 \pm 0.2$ & $1.11 \times 10^{9} \pm 0.72$ & $1.11 \times 10^{4} \pm 1.57$ \\
\hline & & Autumn & 5 & 905 & $4.7 \pm 0.4$ & $1.62 \times 10^{9} \pm 1.4$ & $2.59 \times 10^{3} \pm 2.03$ \\
\hline & \multirow{3}{*}{$\begin{array}{l}\text { Season } \\
\text { (effluent, ESA and EF) }\end{array}$} & Spring & 10 & 2305 & $4.93 \pm 0.6$ & $3.00 \times 10^{9} \pm 2.95$ & $3.08 \times 10^{4} \pm 3.22$ \\
\hline & & Summer & 6 & 2293 & $5.23 \pm 0.6$ & $5.92 \times 10^{8} \pm 5.34$ & $1.04 \times 10^{4} \pm 1.91$ \\
\hline & & Autumn & 4 & 1113 & $4.68 \pm 0.6$ & $1.30 \times 10^{9} \pm 1.29$ & $1.10 \times 10^{5} \pm 1.75$ \\
\hline & Variable & Category & Sample size & ASV richness & Shannon index & $\begin{array}{c}16 S \\
\text { (copies x g) }\end{array}$ & $\begin{array}{c}\text { Int/1 } \\
\text { (copies x g) }\end{array}$ \\
\hline \multirow[t]{2}{*}{ Filter material } & & $F D 1$ & 3 & 848 & $5.3 \pm 0.03$ & $2.72 \times 10^{7} \pm 1.22$ & $2.62 \times 10^{7} \pm 0.67$ \\
\hline & & FD2 & 3 & 1486 & $6.1 \pm 0.1$ & $2.58 \times 10^{7} \pm 2.59$ & $2.67 \times 10^{6} \pm 1.95$ \\
\hline
\end{tabular}


Table 3. Kruskall-Wallis test employed to identify statistical differences in bacterial richness (ASV), diversity (Shannon), $16 \mathrm{~S}$ and Intl1 gene copies along the two SQIDs water treatment. P-value significance codes: $<0.001^{\star * *} ;<0.01^{\star \star} ;<0.05^{*}$. n.a. (not applicable).

\section{Shannon}

\begin{tabular}{|lccc|cc|cc|}
\hline & $\mathbf{n}$ & $\begin{array}{c}\text { Chi- } \\
\text { squared }\end{array}$ & increased in & Chi-squared & increased in & Chi-squared & Increased in \\
\hline D1 Influent vs effluent & 24 & 1.76 & n.a. & 0.65 & n.a. & $3.88^{*}$ & Effluent $(+2.01)$ \\
D2 Influent vs effluent & 17 & $4.28^{*}$ & Effluent $(+1.09)$ & 3 & n.a. & 0.85 & n.a. \\
\hline
\end{tabular}

$16 S$
$\log (16 S$ gene copies $/ \mathrm{mL})$

Intl1

\begin{tabular}{l|ll} 
n.a. & 0.85 & n.a.
\end{tabular} 


\section{Figures}

Figure 1. Distribution bar plot of the relative abundance of bacterial groups at Phylum (A) and Genus (B) level in untreated and treated road runoff and SQIDs' filter media. For better representation only taxa with relative abundance $>2 \%$ are displayed. I: Influent, ES: effluent of sedimentation, SA: effluent of sedimentation and adsorption, EF: effluent of filtration; FD1: filter material of D1; FD2: filter material of D2 (D1 and D2 as depicted in Figure 1.)

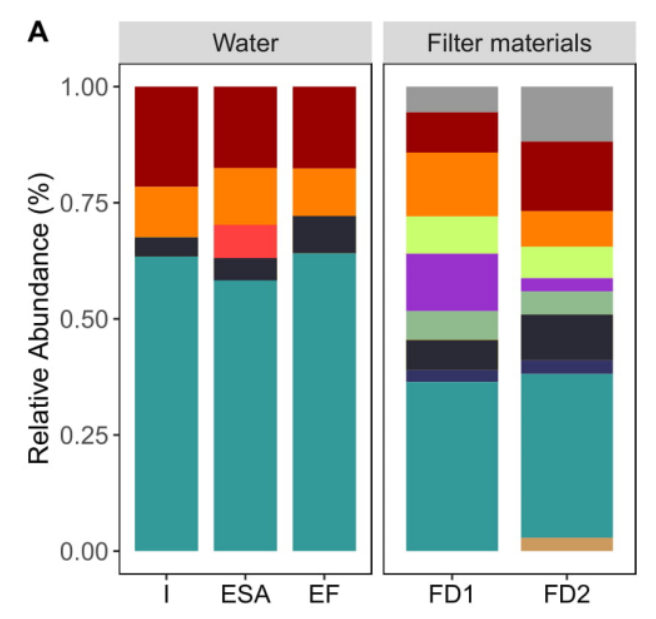

Phylum
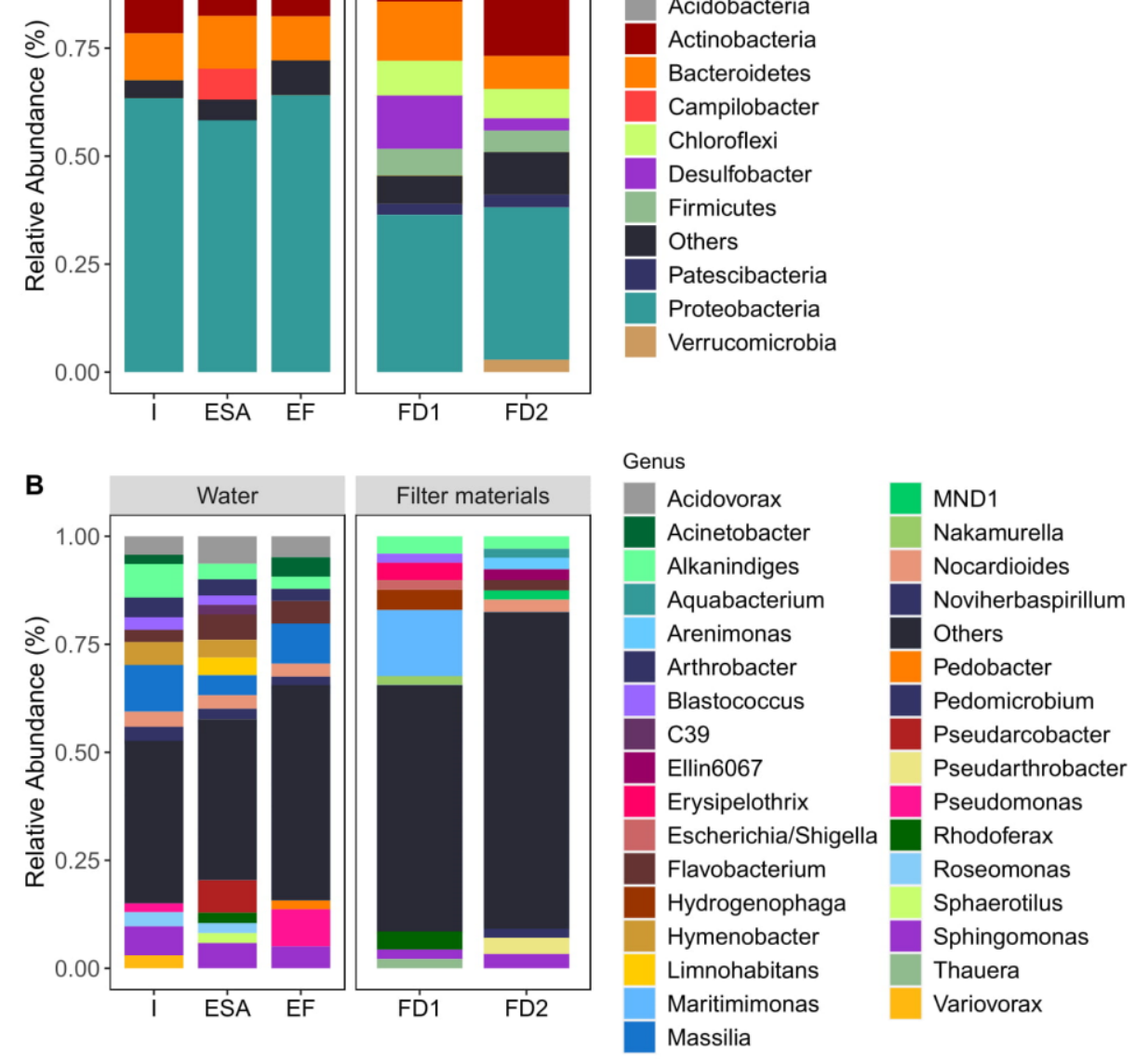
Figure 2. Non-metric multidimensional scaling (NMDS) based on Bray-Curtis dissimilarity of SQIDs effluents community data ( $\mathrm{n}=20$ ) and environmental factors. ESA: effluent of sedimentation and adsorption, EF: effluent of filtration. The correlation between species and environmental variables are indicated by a perpendicular projection of the species arrow-tips onto the line overlaying the environmental variable arrow.

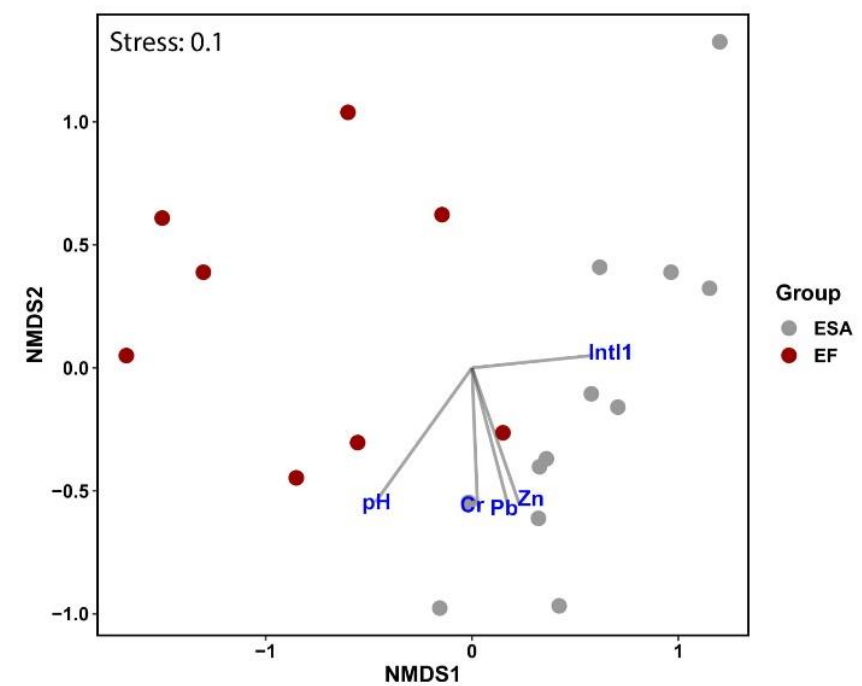

Figure 3. Spearman correlations between biomass normalized int/1 and heavy metals in SQIDs effluent water samples $(n=20$, nickel $(A)$, zinc (B), lead (C)).
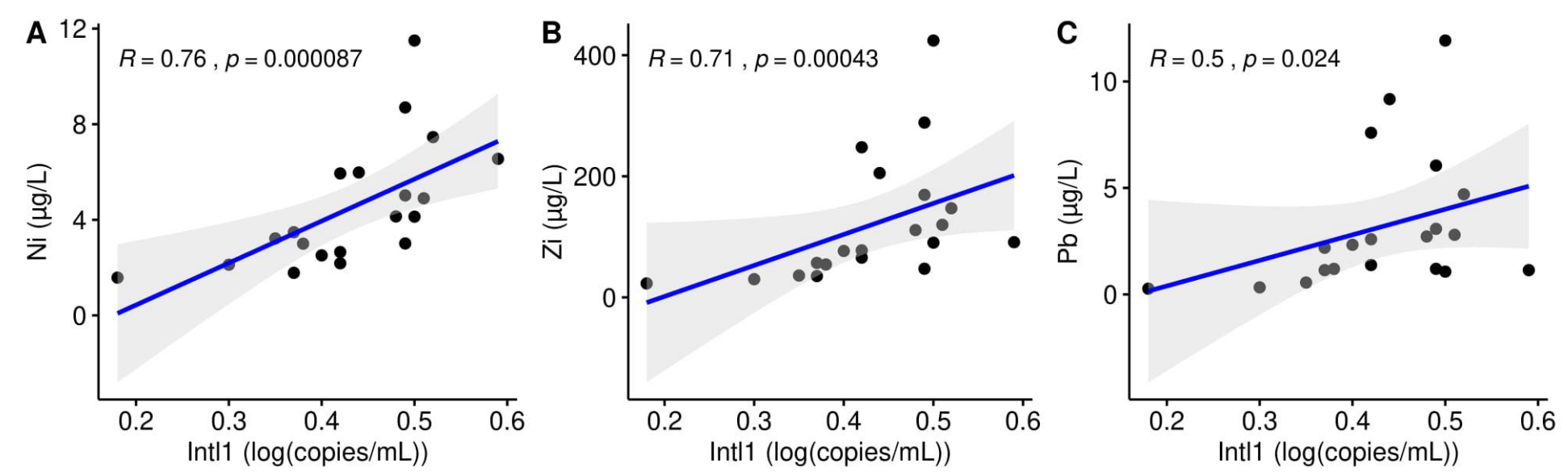
Figure 4. Heat map of Spearman correlation analysis between relative abundance of water effluents $(n=20)$ bacterial community and content of heavy metals at Genus level. Colors depict individual negative and positive correlations.

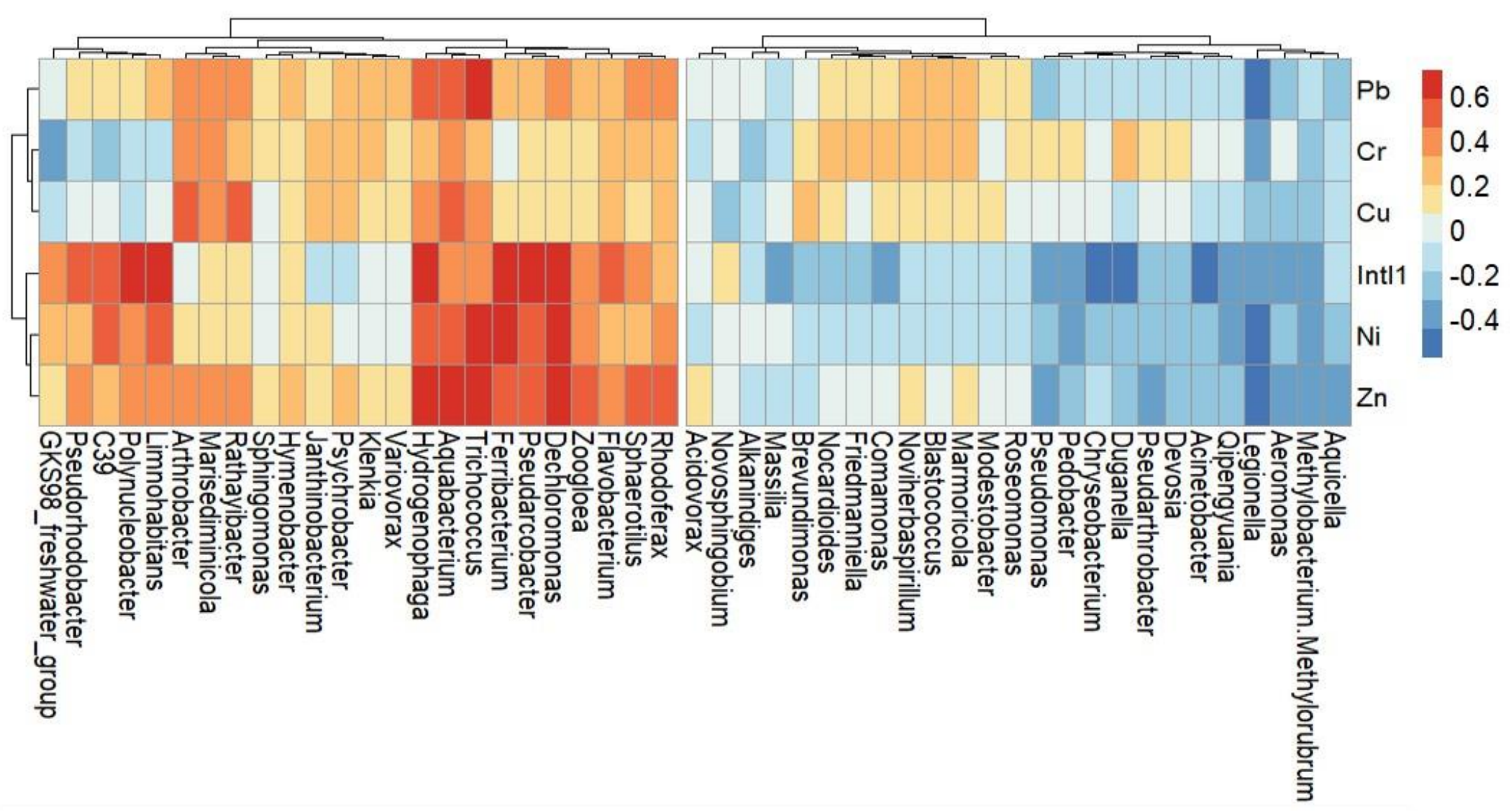


Figure 5. Distribution of different types of resistance genes in the class I integron gene cassette sequences Number of integrons

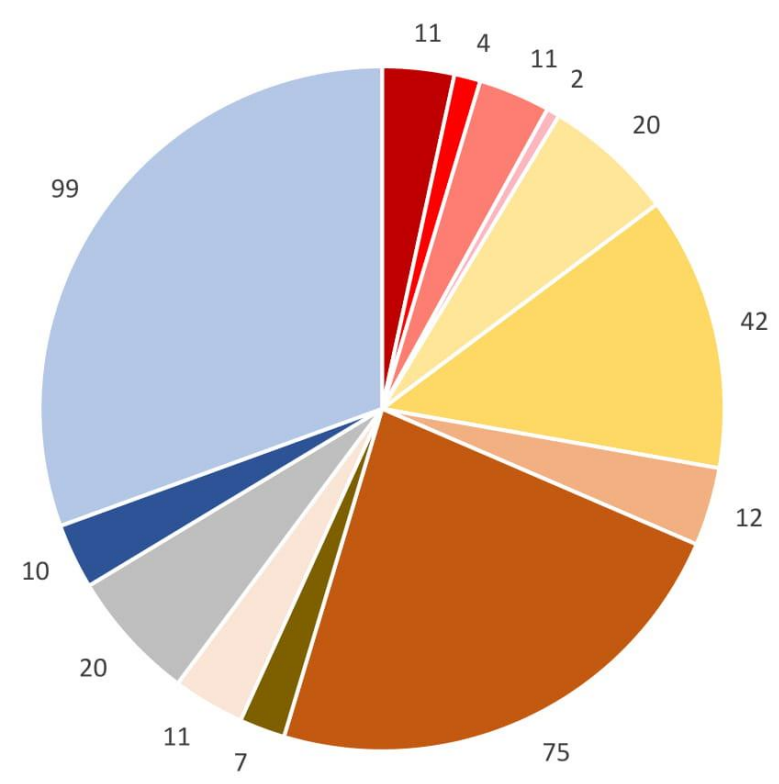

- Aminoglycoside resistance

- Fluoroquinolone resistance

- Multidrug antibiotic resistance

= Other antibiotic resistance

- Arsenic resistance

- Copper/Silver resistance

- Iron/Nickel/Gallium resistance

- Lead/Cadmium/Zinc/Cobalt resistance

- Mercury resistance

Other metal resisttance

- Metal and biocide multiresistance

- Biocide resistance

- Multibiocide resistance 


\section{Supplementary data}

Table S1. Insignificance threshold values for groundwater specified by the Länderarbeitsgemeinschaft Wasser (LAWA) in $\mu \mathrm{g} / \mathrm{L}$, which were used to calculate the water pollution index (WPI $\mathrm{WFS}_{\mathrm{G}}$

\begin{tabular}{ccccc}
$\mathbf{C r}$ & $\mathrm{Cu}$ & $\mathbf{N i}$ & $\mathbf{P b}$ & $\mathbf{Z n}$ \\
\hline 3.4 & 5.4 & 7.0 & 1.2 & 60.0
\end{tabular}

Table S2. List of potential pathogenic taxa identified in road runoff and effluent of stormwater quality improvement devices. ESA: effluent of sedimentation and adsorption, EF: effluent of filtration. All the values are reported as percentages.

\begin{tabular}{|lccc|}
\hline Genus & & & \\
\hline Aeromonas & Influent & ESA & EF \\
Burkholderia-Caballeronia-Paraburkholderia & 0.07 & 0.08 & 0.58 \\
Clostridium_sensu_stricto_1 & 0.01 & 0.03 & 0.10 \\
Corynebacterium & 0.08 & 0.03 & 0.01 \\
Cryptosporangium & 0.03 & 0.16 & 0.05 \\
Enterobacter & - & 0.005 & - \\
Erysipelothrix & 0.004 & 0.001 & - \\
Enterococcus & 0.015 & 0.04 & - \\
Escherichia/Shigella & - & - & 0.006 \\
Legionella & 0.001 & - & - \\
Mycobacterium & 0.03 & 0.08 & 1.91 \\
Pseudomonas & 0.04 & 0.06 & 0.04 \\
Serratia & 2.04 & 0.47 & 8.64 \\
Staphylococcus & 0.01 & 0.007 & 0.009 \\
Yersinia & - & - & 0.05 \\
\end{tabular}


Table S3. Results from PERMANOVA analysis to test the effects of environmental parameters on microbial community composition treated runoff by the two SQIDs (effluents, $n=20$ ). $p$-value

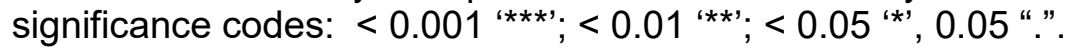

\begin{tabular}{|llll|}
\hline \multicolumn{2}{|l}{} & \multicolumn{2}{c|}{ PERMANOVA } \\
Parameter & $\mathbf{R}^{2}$ & p-value \\
\hline $\mathrm{pH}$ & 20 & 0.09 & $0.01^{* *}$ \\
Intl1 & 20 & 0.08 & $0.03^{*}$ \\
$\mathrm{Cu}$ & 20 & 0.07 & 0.05. \\
$\mathrm{Ni}$ & 20 & 0.11 & $0.0009^{* * *}$ \\
$\mathrm{Zn}$ & 20 & 0.09 & $0.003^{* *}$ \\
\hline
\end{tabular}

Table S4. Resistance genes encountered on at least six of the sequenced integrons

\begin{tabular}{|l|l|l|l|}
\hline Gene & $\begin{array}{l}\text { \# integron } \\
\text { sequences }\end{array}$ & Function & Database \\
\hline CzrA & 24 & $\begin{array}{l}\text { Zn and Cd resistance regulator } \\
\text { Quaternary ammonium compound-resistance } \\
\text { (exporter) }\end{array}$ & BacMet \\
\hline qacE & 20 & Cd, Zn and Co resistance (exporter) & BacMet \\
\hline czcA & 20 & Biocide exporter & BacMet \\
\hline mexW & 14 & Ag efflux system periplasmic chaperone & BacMet \\
\hline silP & 13 & As Sb exporter & BacMet \\
\hline arsB & 10 & $\begin{array}{l}\text { Multidrug efflux transporter (biocide resistance) } \\
\text { Hg reductase enzyme }\end{array}$ & BacMet \\
\hline vexB & 9 & $\begin{array}{l}\text { Multidrug efflux protein (substrates include biocides as } \\
\text { well as the antibiotics ampicillin and chloramphenicol) }\end{array}$ & BacMet \\
\hline merA & 7 & $\begin{array}{l}\text { Multidrug efflux protein (including antibiotics ampicillin } \\
\text { and novobiocin) }\end{array}$ & BacMet \\
\hline acrB & 7 & $\begin{array}{l}\text { DNA repair protein, involved in Cr, Te and Se } \\
\text { resistance }\end{array}$ & BacMet \\
\hline vexH & 6 & $\begin{array}{l}\text { Cation transport ARPase, involved in Fe and Ni } \\
\text { resistance }\end{array}$ & BacMet \\
\hline recG & 6 & Multidrug efflux transporter (biocide resistance) & BacMet \\
\hline nia & 6 & aminoglycoside nucleotidyltransferase & ResFinder \\
\hline adeE & 6 & & \\
\hline aadA5 & 6 & & \\
\hline & & & \\
\hline
\end{tabular}


bioRxiv preprint doi: https://doi.org/10.1101/2021.01.12.426166; this version posted March 24, 2021. The copyright holder for this preprint (which was not certified by peer review) is the author/funder, who has granted bioRxiv a license to display the preprint in perpetuity. It is made available under aCC-BY-NC-ND 4.0 International license.

Figure S1. Structure and treatment processes of the monitored SQIDs. Name of the two SQIDs are shown in green (D1 and D2), main processes are showed in gray boxes, effluents classification are in blue boxes. ESA: Effluent of Sedimentation and Adsorption, EF: Effluent of Filtration. The arrows depict the flow of the water.

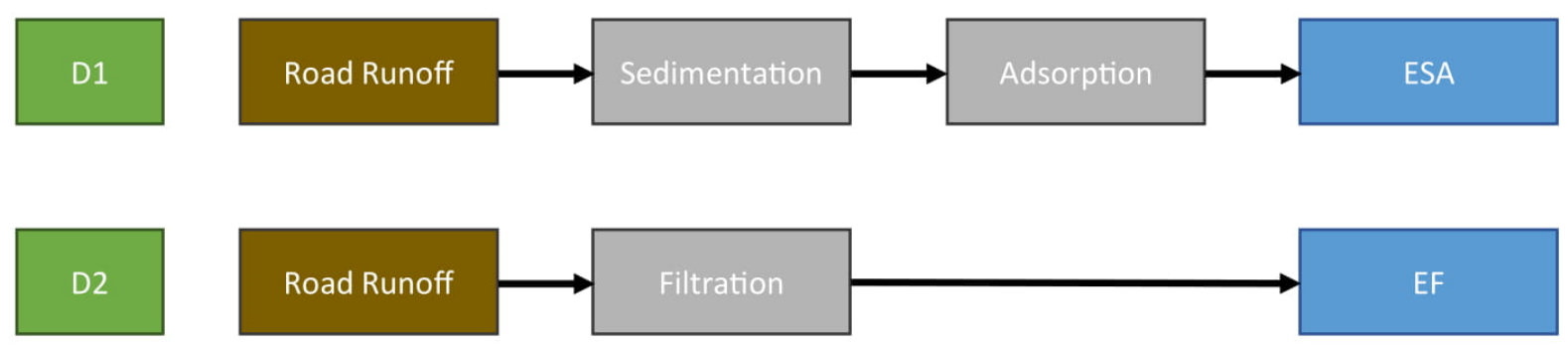

Figure S2. Distribution bar plot of the relative abundance of bacteria community at Phylum $(A)$ and Genus (B) level along different depth layers of filter media samples. Surface $(0-5 \mathrm{~cm})$, Medium (5$10 \mathrm{~cm})$, Deep $(10-15 \mathrm{~cm})$. For the best representation only taxa with relative abundance $>2 \%$ are displayed.

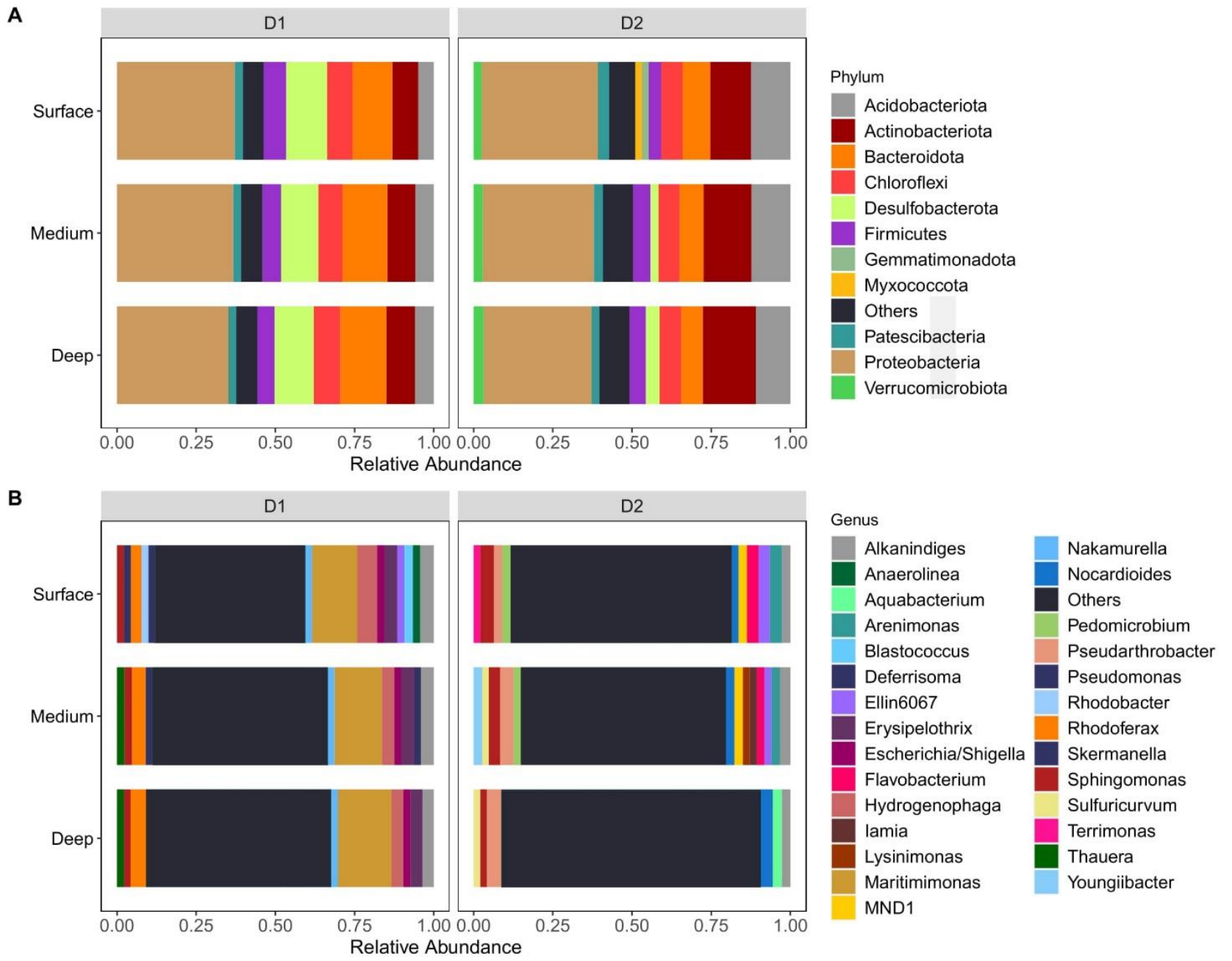


bioRxiv preprint doi: $h$ ttps://doi.org/10.1101/2021.01.12.426166: this version posted March 24, 2021. The copyright holder for this preprint (which was not certified by peer review) is the author/funder, who has granted bioRxiv a license to display the preprint in perpetuity. It is made available under aCC-BY-NC-ND 4.0 International license.

Figure S3. Differential abundance analysis of bacterial relative abundance in D1 (A) and in D2 (B) effluents $(n=20)$ compared to those of the influent. Core taxa with statistically significant difference (log2FC > \pm 2 ; adjusted p-value $<0.05$ ) are displayed in the plot. The different colours depict bacterial phyla. Red arrow indicate taxa present in the influent, black arrow show taxa in the effluents.

A

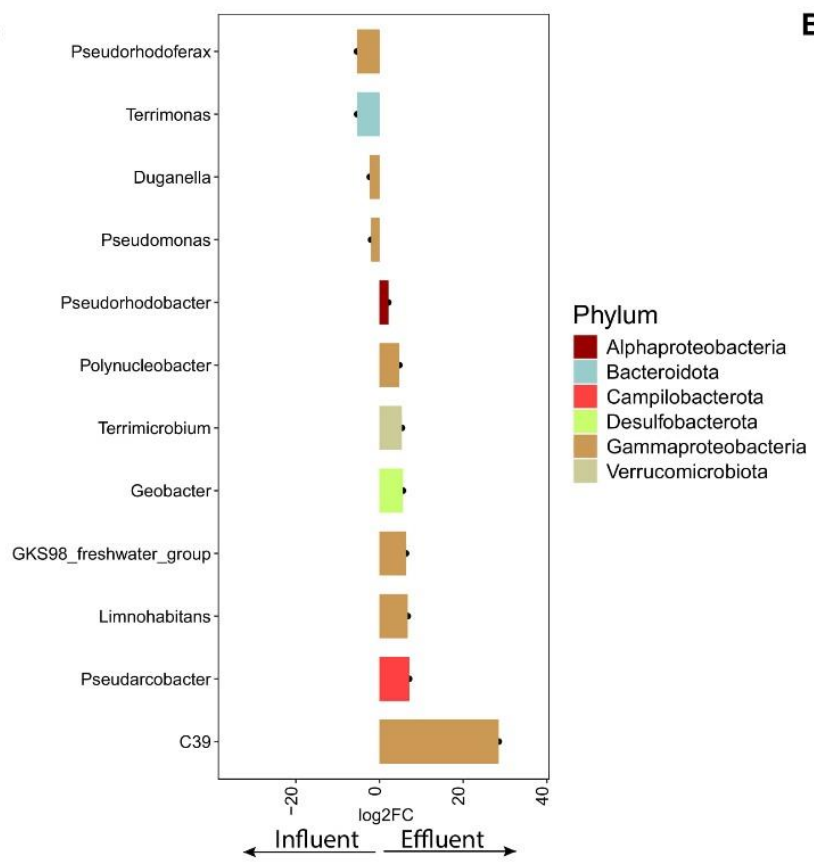

B

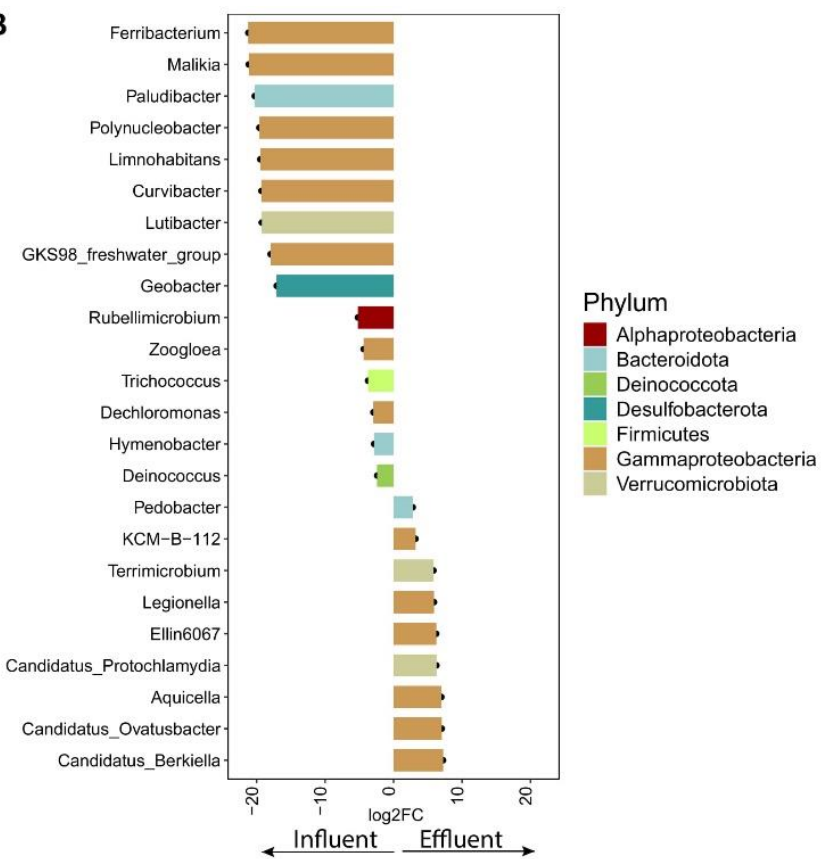

